\title{
MICROBIOLOGICAL AND PATHOLOGICAL STUDIES ON HIGH MORTALITY RATE IN SUCKLING CALVES WITH SPECIAL REFERENCE TO EPIDEMIOLOGICAL IMPACT
}

\author{
NABIH, A.M. ${ }^{1}$; NIBAL A. HASSAN ${ }^{1}$; HANAA, A. ELHALAWANY ${ }^{1}$; HALA A. SALEM ${ }^{1}$ and \\ AHMAD H. FATHY ${ }^{2}$ \\ ${ }^{1}$ Animal Reproduction Research Institute (ARRI) Giza, Egypt \\ ${ }^{2}$ General Organization for Vetrinary Services
}

Received: 5 March 2017; Accepted: 26 April 2017

\begin{abstract}
The current study aims to investigate the causes of high mortality rate in suckling calves due to bacterial and viral infection in relation to locality, seasons and age as well as through a high light on the histopathological effect of isolated organisms on tissues of dead suckling calves using both light and electron microscope. This work was performed on a total number of 144(25.1\%) dead calves from total reported diseased 573 suckling calves. Samples collected from Al Sharquia, Al Behaira and Al Giza Governorates of Egypt during May 2016 to February, 2017. The mortality rate recorded in Al Sharquia, Al Behaira and Al Giza in percentage of 31.2\%, $22.4 \%$ and $18.6 \%$ respectively. Mortality rate was more prevalence in winter $69.4 \%$ than summer $30.6 \%$. Enteritis cases were reported in $13.2 \%$, Pneumonia represented $21.5 \%$ while pneumoentritis was $65.3 \%$. Isolated bacteria and viruses from out of 144 suckling dead calves suffering from enteritis were Escherichia coli (E. coli) $2.08 \%$, Salmonella typhimurium (S. typhimurium) 2.7\% mixed infection of BVDV with E. coli $4.1 \%$, and mixed of Rota virus with $S$. typhimurium in $4.1 \%$ of cases. In Pneumonic Calves, the most prevalence isolates were Pasteurella multocida (P. multocida) $6.9 \%$ followed by Bovine Viral Diarrhea virus (BVDV), as a single infection, $6.2 \%$, meanwhile mixed infection of both microorganesms were $15.2 \%$. On the other hand, mixed isolates, bacteria and viruses, from 144 suckling dead calves suffering from pnemoentritis were represented in $84(58.4 \%)$ cases of dead examined calf, Isolated organisms were mixed infection of BVDV with $S$. typhimurium and E. coli $13.8 \%$, other cases showed mixed infection of BVD with S. typhimurium $13.8 \%$, other cases showed mixed of P.multocida with S. typhimurium $13.1 \%$ finally cases of mixed infection of BVD with E.coli and P.multocida 18.7\%. Pathological examination of Pneumonic calves revealed marked changes represented by two types of pneumonia which observed as Acute fibrinosuppurative bronchopneumonia (6.9\%), and Interstitial pleuropneumonia (21.5\%), entric calves revealed Hemorrhagic enteritis (13.2) \%. In addition, in pneumoentric calves which represented $58.4 \%$ of dead calves and showed, Fibrino-necrotizing bronchopneumonia, Necrotizing ulcerative enteritis, lymphocytic hepatitis with congestive cirrhosis, Interstitial nephritis, Acute hemorrhagic myocarditis and Splenic lymphoid depletion.
\end{abstract}

Key words: Microbiological, Pathological, Suckling Calves, Epidemiological.

\section{INTRODUCTION}

Calf mortality is now considered as an indicator to animal health and to production level. So farmers are working to keep mortality rates low in all seasons. The main etiology of calf mortality usually includes pneumonia, enteritis and septicemia (Pardon et al., 2012). Pneumonia is often referred to bovine respiratory disease Complex (BRDC) which caused by stress, virus, and bacterial agents, that often

Corresponding author: Dr. NABIH, A.M.

E-mail address: ashraf_nabih27@yahoo.com

Present address: Animal Reproduction Research Institute (ARRI) Giza, Egypt produce mild to severe clinical signs and death within 24 to 36 hours or may cause permanent lung damage as fibrosis, adhesions and death (Zaher et al., 2014 and Voiriot et al., 2016). Although a single viral agent may be a primary invader when the local resistance of respiratory mucosa is lowered, bacterial flora that normal inhabitants of the nasopharynx extend downwards and producing multiple bacterial Infections. (Shoshani et al., 2013). Bovine viral diarrhea virus (BVDV), P. multocida and other bacteria are considered the most BRDC of bovine that associated with respiratory infection with severe pneumonic damage. This damage characterized by pulmonary invasion through the production of virulence factors that facilitate colonization in the lower respiratory tract and may resulting in enteric infections with a higher risk of a severe illness as well 
as high mortality rates. Moreover replication of BVDV in lymphoid tissue may interfere with normal local and systemic immune functions, thereby weakening immune defense mechanisms and enhancing disease processes induced by respiratory and enteric pathogens in mixed infections (Crook et al., 2012 and Torres et al., 2013).

Calf diarrhea is a multifactorial disease. It has been estimated that $75 \%$ of early calf mortality in dairy herds is caused by acute diarrhea in the pre-weaning period, and also still a major cause of economic loss to cattle producers. Various infectious agents such as viruses and bacteria are involved in calf diarrhea (Bartels et al., 2010 and Muktar et al., 2015). The most common pathogenic agents of neonatal enteritis complex that leading to high mortality are rotavirus, BVDV, S. typhimurium, E. coli and P. multocida which are responsible for more than $50 \%$ of all neonatal diarrheas during the first week. Only $15 \%$ occur after the second week of life, exceptionally, the highest prevalence of rotavirus is seen at 2-4weeks of age (Nour mohammad zadeh et al., 2011). Rotavirus is the major cause of profuse diarrhea and severe dehydration in neonates of many domestic animals (Dhama 2009). The causes of mortality are complex microbial infection, with other stress factors like the environments, nutrition, hygienic care, depraved Colostrum, low immunity, vaccination of pregnant cows and neonatal calves. All previously mentioned etiologic agents are involved in an outbreaks of acute disease which lead to high mortality in calves (Razzaque et al., 2009 and Aziz zadeh et al., 2012).

The current study designed to investigate the causes of high mortality rate in suckling calves due to bacterial and viral infection in relation to the season it also spots some light on the micro morphological and ultrastructural changes induced by the isolated organisms on tissues of dead suckling calves using both light and electron microscope.

\section{MATERIALS AND METHODS}

\section{Animals:}

This work was performed on a total number of 144 dead calves from total reported 573 suckling cattle calves aged from 1-15 days from Al Sharquia, Al Behaira and Al Giza Governorates during May, 2016 to February, 2017.

\section{Samples}

Three swabs were collected aseptically from each examined calf first nasal swab was collected on brain heart broth for P.multocida cultivation. Second fecal swab was collected on selenite F. broth for isolation of salmonella spp., while third fecal one was collected on nutrient broth for other general bacteriological examination specially for E.coli isolation. Moreover internal organs (lung, intestine, liver, spleen, kidney and heart), were collected from each examined dead calf on aseptic plastic bags and transported directly to bacteriological lab. in ice box for bacteriological examination.

\section{Bacterial isolation and identification:}

Cultural and biochemical identification:

Nasal swabs which immersed in brain heart broth which cultured on brain heart infusion agar supplemented with 5\% defebrinated sheep blood, blood agar and macconkey agar for P.multocida and E. coli isolation. In addition, salmonella-sheigella agar (S.S.agar) for isolation of salmonella spp. Plates were incubated at $37^{\circ} \mathrm{C}$ for 24 hours (Kodjo et al., 1999). All isolated bacteria were identified by colony morphology, Gram staining, and biochemical reactions mostly includes oxidase, catalase, urease tests, triple sugar iron agar, motility tests, indol tests, voges proskauer and sugars fermintation tests, in addition to serological identification of salmonella and pasterulla serotypes. (Baily and Scotts, 1998).

\section{Virological studies:}

1- Virus strains: -Bovine Viral Diarrhea (BVD) NADL strain (AHRI) and Bovine RotaVirus (BRV) local isolated (SVRI).

2- Positive sera: positive hyperimmune serum of BVD and BRV.

3- Fluorescent Antibody Technique: (Indirect immuno fluorescent technique (Indirect IFAT): was carried out according to, OIE standers (1992).

4- Immunoperoxidase test: as described by Meyling, (1984)

5- Rotavirus Rapid Test (latex test)

\subsection{Histopathological examination:}

Specimens from organs that showing lesions, (lungs, liver, intestine, spleen, lymph nodes and kidneys) were fixed in $10 \%$ formalin then processed for histopathological examination as described by Suvarna et al. (2013).

\subsection{Electron microscopy:}

Some of positive samples suspension was used for electron microscopy according to Madbouly et al. (2005)

\subsection{Epidemiological investigations:}

Epidemiological parameters were estimated according to Martin et al. (1987). 


\section{RESULTS}

Table (1): Prevalence of mortality rate in suckling calves according to locality, age and season.

\begin{tabular}{|c|c|c|c|c|c|c|c|c|c|c|c|c|c|c|c|}
\hline \multicolumn{8}{|c|}{ Locality } & \multicolumn{4}{|c|}{ Age } & \multicolumn{4}{|c|}{ season } \\
\hline \multicolumn{2}{|c|}{ Al Sharquia } & \multicolumn{2}{|c|}{ Al Behaira } & \multicolumn{2}{|c|}{ Al Giza } & \multicolumn{2}{|c|}{ Total } & \multicolumn{2}{|c|}{ 1-7 days } & \multicolumn{2}{|c|}{ 8-15 days } & \multicolumn{2}{|c|}{ Summer } & \multicolumn{2}{|c|}{ Winter } \\
\hline No. & $\%$ & No. & $\%$ & No. & $\%$ & No. & $\%$ & No. & $\%$ & No. & $\%$ & No. & $\%$ & No. & $\%$ \\
\hline $74 / 237$ & 31.2 & $44 / 196$ & 22.4 & $26 / 140$ & 18.6 & $44 / 573$ & 25.1 & $89 / 144$ & 61.8 & $55 / 144$ & 38.2 & $44 / 144$ & 30.6 & $100 / 144$ & 69.4 \\
\hline
\end{tabular}

Table 2: Prevalence of mortality rate in suckling calves according symptoms in three Governorates.

\begin{tabular}{lccccccccc}
\hline \multirow{2}{*}{ Diseases } & \multicolumn{2}{c}{ Al Sharquia } & \multicolumn{2}{c}{ Al Behaira } & \multicolumn{2}{c}{ Al Giza } & \multicolumn{2}{c}{ Total } \\
\cline { 2 - 10 } & No. & $\%$ & No. & $\%$ & No. & $\%$ & No. & $\%$ \\
\hline Pneumonia & 21 & 14.5 & 12 & 8.3 & 8 & 5.5 & 41 & 28.4 \\
\hline Enteritis- & 11 & 7.6 & 5 & 3.4 & 3 & 2.8 & 19 & 13.2 \\
\hline Pneumoenterites & 43 & 29.8 & 26 & 18.05 & 15 & 10.4 & 84 & 58.4 \\
\hline Total & 75 & 51.4 & 43 & 29.8 & 27 & 18.7 & 144 & $100 \%$ \\
\hline
\end{tabular}

\section{Egypt Map}

Selected Suckling Calves' Farms

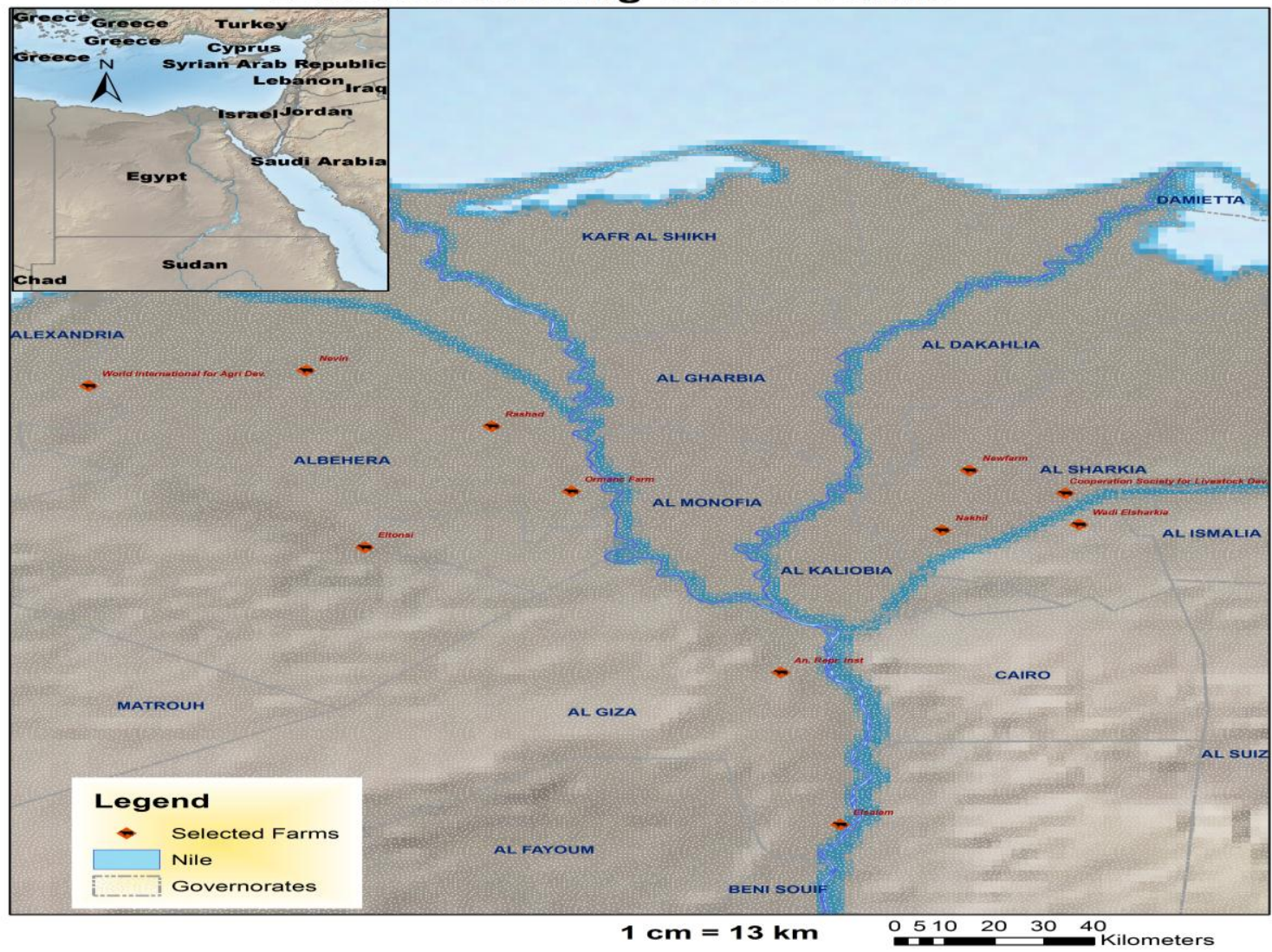


Table 3: Isolated bacteria and viruses from 41 out 144 suckling dead calves suffering from pnemonia according to locality, age and season.

\begin{tabular}{|c|c|c|c|c|c|c|c|c|c|c|c|c|c|c|c|c|}
\hline \multirow[t]{3}{*}{ Microbial isolates } & \multicolumn{8}{|c|}{ Locality } & \multicolumn{4}{|c|}{ Age } & \multicolumn{4}{|c|}{ Season } \\
\hline & \multicolumn{2}{|c|}{$\begin{array}{c}\text { Al } \\
\text { Sharquia }\end{array}$} & \multicolumn{2}{|c|}{ Al Behaira } & \multicolumn{2}{|c|}{ Al Giza } & \multicolumn{2}{|c|}{ Total } & \multicolumn{2}{|c|}{ 1-7 days } & \multicolumn{2}{|c|}{$\begin{array}{l}8-15 \\
\text { days }\end{array}$} & \multicolumn{2}{|c|}{ Summer } & \multicolumn{2}{|c|}{ Winter } \\
\hline & No & $\%$ & No. & $\%$ & No. & $\%$ & No. & $\%$ & No. & $\%$ & No. & $\%$ & No. & $\%$ & No. & $\%$ \\
\hline BVDV & 4 & 2.8 & 3 & 2.08 & 2 & 1.38 & 9 & 6.2 & 6 & 4.1 & 3 & 2.08 & 2 & 1.38 & 7 & 4.8 \\
\hline P. multocida & 6 & 4.1 & 2 & 1.38 & 2 & 1.38 & 10 & 6.9 & 8 & 5.5 & 2 & 1.38 & 3 & 2.08 & 7 & 4.8 \\
\hline BVDV $+P$. multocida & 11 & 7.63 & 7 & 3.4 & 4 & 2.8 & 22 & 15.2 & 17 & 11.8 & 5 & 3.4 & 6 & 4.1 & 16 & 11.1 \\
\hline
\end{tabular}

Table 4: Isolated bacteria and viruses from 19 out 144 suckling dead calves suffering from enteritis according to locality, age and season

\begin{tabular}{|c|c|c|c|c|c|c|c|c|c|c|c|c|c|c|c|c|}
\hline \multirow{3}{*}{$\begin{array}{l}\text { Microbial } \\
\text { isolates }\end{array}$} & \multicolumn{8}{|c|}{ Locality } & \multicolumn{4}{|c|}{ Age } & \multicolumn{4}{|c|}{ Season } \\
\hline & \multicolumn{2}{|c|}{ Al Sharquia } & \multicolumn{2}{|c|}{ Al Behaira } & \multicolumn{2}{|c|}{ Al Giza } & \multicolumn{2}{|c|}{ Total } & \multicolumn{2}{|c|}{ 1-7 days } & \multicolumn{2}{|c|}{$\begin{array}{l}8-15 \\
\text { days }\end{array}$} & \multicolumn{2}{|c|}{ Summer } & \multicolumn{2}{|c|}{ Winter } \\
\hline & No & $\%$ & No. & $\%$ & No. & $\%$ & No. & $\%$ & No. & $\%$ & No. & $\%$ & No. & $\%$ & No. & \\
\hline E.coli & 2 & 1.38 & 1 & 0.69 & zero & 0.0 & 3 & 2.08 & 2 & 1.38 & 1 & 0.69 & 2 & 1.38 & 1 & 0.69 \\
\hline S. typhimurium & 3 & 2.08 & 1 & 0.69 & zero & 0.0 & 4 & 2.7 & 3 & 2.08 & 1 & 0.69 & 3 & 2.08 & 1 & 0.69 \\
\hline BVD+ E.coli & 4 & 2.7 & zero & 0.0 & 2 & 2.08 & 6 & 4.1 & 4 & 2.7 & 2 & 1.38 & 1 & 0.69 & 5 & 3.4 \\
\hline $\begin{array}{l}\text { BRV + S. } \\
\text { typhimurium }\end{array}$ & 2 & 1.38 & 3 & 2.08 & 1 & 0.69 & 6 & 4.1 & 5 & 3.4 & 1 & 0.69 & 1 & 0.69 & 5 & 3.4 \\
\hline
\end{tabular}

Table 5: Isolated bacteria and viruses from 84 out of 144 suckling dead calves suffering from pneumoentris according to locality, age and season.

\begin{tabular}{|c|c|c|c|c|c|c|c|c|c|c|c|c|c|c|c|c|}
\hline \multirow{3}{*}{ Microbial isolates } & \multicolumn{8}{|c|}{ Locality } & \multicolumn{4}{|c|}{ Age } & \multicolumn{4}{|c|}{ Season } \\
\hline & \multicolumn{2}{|c|}{$\begin{array}{c}\text { Al } \\
\text { Sharquia }\end{array}$} & \multicolumn{2}{|c|}{$\begin{array}{c}\text { Al } \\
\text { Behaira }\end{array}$} & \multicolumn{2}{|c|}{ Al Giza } & \multicolumn{2}{|c|}{ Total } & \multicolumn{2}{|c|}{ 1-7 days } & \multicolumn{2}{|c|}{$\begin{array}{l}8-15 \\
\text { days }\end{array}$} & \multicolumn{2}{|c|}{ Summer } & \multicolumn{2}{|c|}{ Winter } \\
\hline & No & $\%$ & No. & $\%$ & No. & $\%$ & No. & $\%$ & No. & $\%$ & No. & $\%$ & No. & $\%$ & No. & $\%$ \\
\hline $\begin{array}{l}\text { BVD+ S. } \\
\text { typhimurium +E.coli }\end{array}$ & 10 & 6.9 & 4 & 2.7 & 6 & 4.1 & 20 & 13.8 & 14 & 9.7 & 6 & 4.1 & 7 & 4.8 & 13 & 9.02 \\
\hline $\begin{array}{l}\text { BVD + S. } \\
\text { typhimurium }\end{array}$ & 12 & 8.3 & 5 & 3.4 & 3 & 2.8 & 20 & 13.8 & 13 & 9.02 & 7 & 4.8 & 6 & 4.1 & 14 & 9.7 \\
\hline $\begin{array}{l}\text { P.multocida }+\mathrm{S} . \\
\text { typhimurium }\end{array}$ & 6 & 4.1 & 11 & 7.6 & 2 & 1.3 & 19 & 13.1 & 14 & 9.7 & 5 & 3.4 & 8 & 5.5 & 11 & 7.6 \\
\hline $\begin{array}{l}\text { BVD+ E.coli } \\
+P . \text { multocida }\end{array}$ & 17 & 11.8 & 6 & 4.1 & 4 & 2.7 & 27 & 18.7 & 19 & 13.1 & 8 & 5.5 & 9 & 6.2 & 18 & 12.5 \\
\hline
\end{tabular}




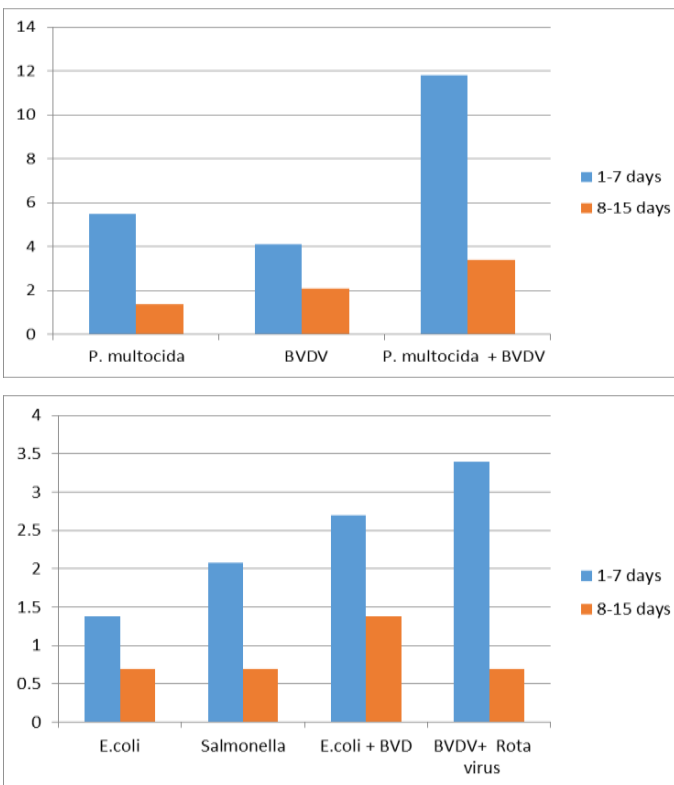

(a)

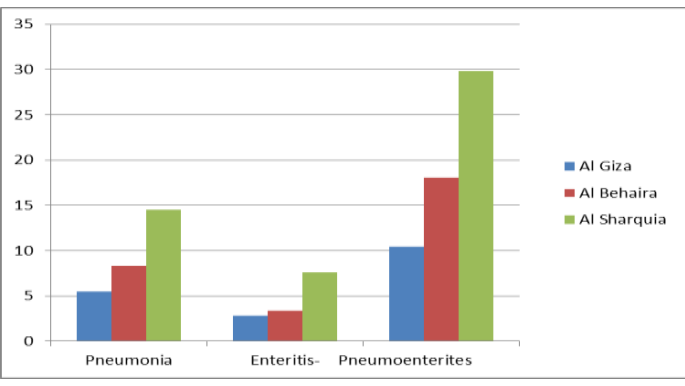

(b)

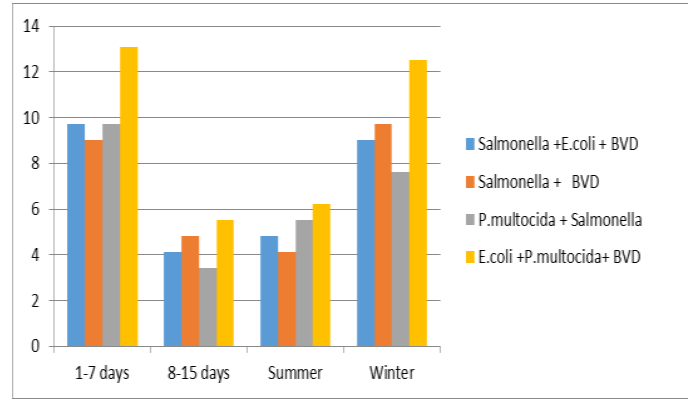

(d)

Figure 2: (a) Prevalence of mortality rate in suckling calves in three Governorates. (b) incidence of Isolated bacteria and viruses from pneumonic dead calves correlated to locality, age and season. (c) incidence of Isolated bacteria and viruses from enteric dead calves related to locality, age and season. (d) incidence of Isolated bacteria and viruses from pneumoentris dead calves related to locality, age and season.

\section{Demonstration of BVD and Rota viruses:}

Table 6: Virological detection and isolation results:

\begin{tabular}{lcccccccc}
\hline Viral antigen & Lung & Liver & Heart & Spleen & $\begin{array}{c}\text { Nasal } \\
\text { swab }\end{array}$ & $\begin{array}{c}\text { Fecal } \\
\text { sample }\end{array}$ & $\begin{array}{c}\text { Mesenteric } \\
\text { L.N }\end{array}$ & Kidney \\
\hline BVD & + & + & + & + & + & + & + & + \\
\hline BRV & - & & & & & & + & \\
\hline
\end{tabular}

Table 7: Tests for detection of BVD and BRV

\begin{tabular}{lccc}
\hline Viral antigen & RRTD & FA & IMP \\
\hline BVDV & - & + & + \\
\hline BRV & + & + & - \\
\hline
\end{tabular}

\section{Histopathology results:}

Table 8: Relationship Between Microscopical Examination And Types Of Isolated Microorganisms In Different Organs Of Examined (144) Dead Calves Tissues:

\begin{tabular}{|c|c|c|c|c|c|}
\hline Mortalities & Organ & Lesion & Isolated organisms & NO. & $\%$ \\
\hline \multirow[t]{2}{*}{ Pneumonia } & lung & $\begin{array}{l}\text { Acute fibrino -suppurative } \\
\text { pneumonia }\end{array}$ & P.multocida, & 10 & 6.9 \\
\hline & & Interstitial-pleuro pneumonia & BVDV, P.multocida and, BVDV & 31 & 21.5 \\
\hline \multirow[t]{3}{*}{ Enteritis } & Intestine & Hemorrhagic enteritis & \multirow{3}{*}{$\begin{array}{l}\text { E. coli, S. typhimurium, BVD } \\
\text { with E.coli and BRV with S. } \\
\text { typhimurium }\end{array}$} & \multirow[t]{3}{*}{19} & \multirow[t]{3}{*}{13.2} \\
\hline & $\begin{array}{l}\text { Mesenteric } \\
\text { L.n. }\end{array}$ & lymphoid depletion & & & \\
\hline & liver & $\begin{array}{l}\text { Highly dilated sinusoids, } \\
\text { lymphocytic infiltrations and } \\
\text { fibrosis around central vein }\end{array}$ & & & \\
\hline \multirow[t]{5}{*}{ Pnemoentri-tis } & lung & $\begin{array}{l}\text { Fibrino necrotizing pneumonia } \\
\text { necrotizing }\end{array}$ & \multirow{5}{*}{$\begin{array}{l}\text { BVDV, S. typhimurium with E. } \\
\text { coli } \\
\text { BVDV+ S. typhimurium } \\
\text { P.multocida } \quad \text { with } S . \\
\text { typhimurium. and } B V D V+ \\
\text { E.coli+ P.multocida }\end{array}$} & \multirow[t]{5}{*}{84} & \multirow[t]{5}{*}{58.4} \\
\hline & Intestine & Heamorhagic ulcerative enteritis & & & \\
\hline & heart & Acute hemorrhagic myocarditis & & & \\
\hline & Spleen & lymphoid depletion & & & \\
\hline & Kidney & Interstitial nephritis & & & \\
\hline
\end{tabular}




\section{FIGURES}
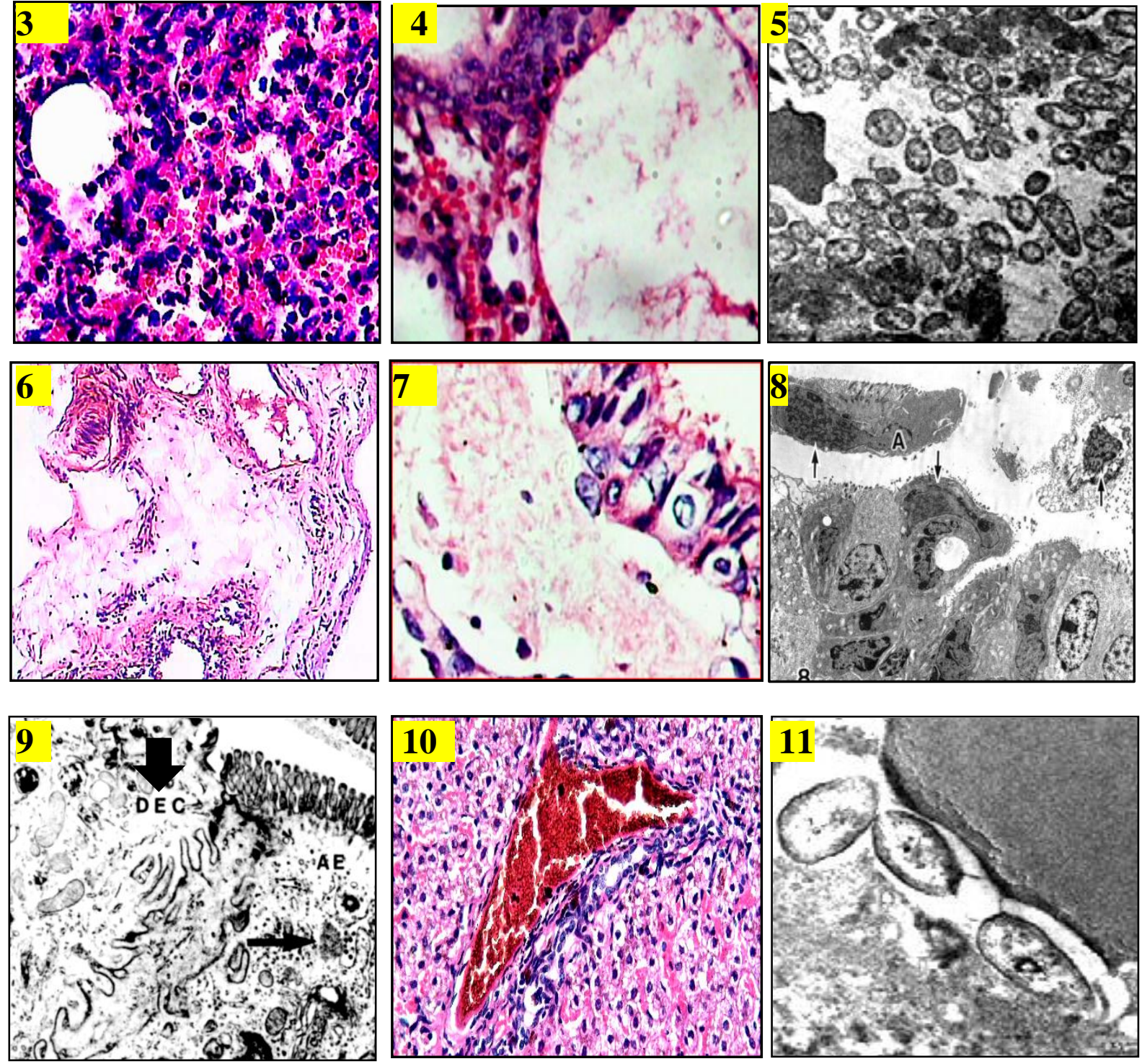

(Fig. 3): Calve lung showed accumulation of neutrophils, macrophages, in the alveolar lumens., periaveolar vascular congestion (H\&E) x40

(Fig. 4): Calve lung showed thickening of the inter alveolar septa with mononuclear cellular aggregates and red blood cells (H\&E) x40

(Fig. 5): TEM micrograph of calf lung showing numerous short rod bacterial cells surrounded by halo space of P. multocida ( $x 2500)$.

(Fig. 6): Calve Pleura showed edema, thickening, vasculitis and mononuclear cellular infiltrations (H\&E) x10

(Fig. 7): Calve lung showed bronchial epithelial cells revealed vacuolar degeneration with lymphocytic exocytosis, and Sub epithelial lymphocytic infiltrations (H\&E) x40

(Fig. 8): TEM micrograph of calve lung showing BVD inclusion bodies in the ciliated bronchiolar epithelial cells (arrows) and desquamated ciliated cells.X 2500

(Fig. 9): TEM micrograph of densely packed BVD virus-like particles in vesicles (arrows) present within enterocytes x 2500

(Fig. 10): Calve liver showed dilated congested sinusoids, lymphocytic infiltrations and perivascular fibro plastic proliferations in the portal area $(\mathrm{H} \& \mathrm{E}) \times 4$

(Fig. 11): TEM micrograph Viral particles were present within reticuloendothelial cells of mesenteric lymph nodes $\mathrm{x} 2500$. 

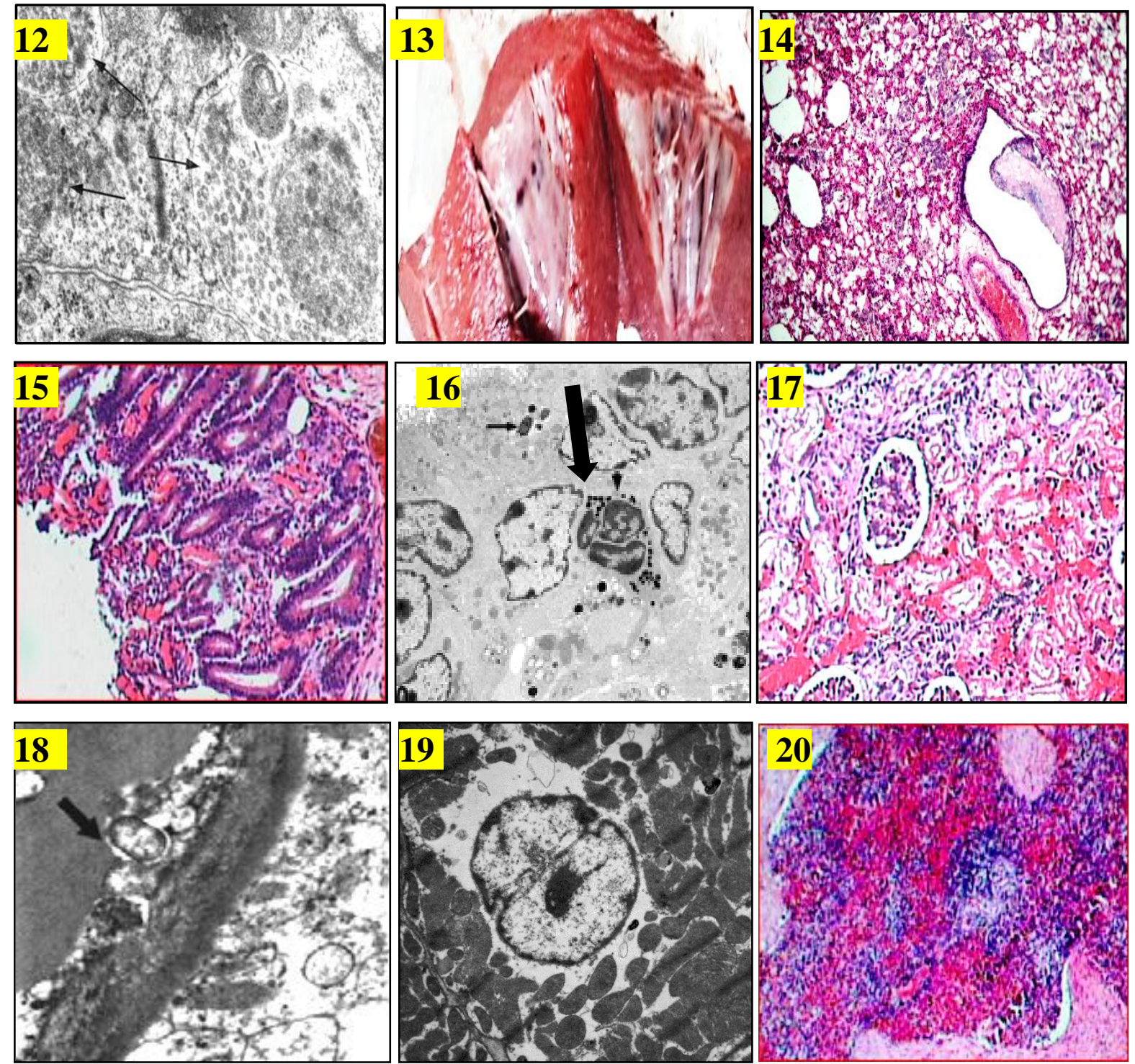

(Fig. 12): TEM micrograph of Calve mesenteric lymph nodes, showing viral particles were present within The reticuloendothelial cells of mesenteric lymph nodes $\mathrm{x} 2500$.

(Fig. 13): Calve heart showed small poetical hemorrhages on the endocardium surface.

(Fig.14): Calve lung 1 showedl Alveoli atelectasis, emphysema, alveolar necrosis sever vascular congestion and occluded bronchiolar lumens(H\&E) x4

(Fig.15): Calve intestine of calve revealed necrotizing ulcerative enteritis with detached villi and hypertrophied intestinal crypts(H\&E) $\mathrm{x} 4$

(Fig.16): TEM micrograph of Calve Ileal villus epithelial cell showing Rotavirus particle appears to be budding (arrows) into the dilated cisternae of rough endoplasmic reticulum.x4500

(Fig.17): Calve kidney showed Sever peritubular vascular congestion and tubular vacuolar degeneration, interstitial nephritis, (H\&E) x10

(Fig.18): TEM micrograph of Calve kidney showing $P$. multocida attached to the basement membrane of a capillary (arrow). (x2500).

(Fig.19): TEM micrograph of Calve heart showing the perinucleur area contains electron lucent material manifesting edema (arrow) of the cell. The cell contains numerous mitochondria $\mathrm{x} 4500$

(Fig.20): Calve spleen showed lymphoid depletion, oedema subcabsolar and peri trabecular hemorrhages, mononuclear inflammatory cell infiltrations (H\&E) x4 


\section{DISCUSSION}

1. mortality rate and symptomes in suckling calves according to locality, age and season

In the present study, out of reported 573 diseased calves $144(25.1 \%)$ were dead in different farms at $\mathrm{Al}$ Sharquia, Al Behaira and Al Giza Governorates of Egypt during May 2016 to February, 2017. The mortality rate recorded in Al Sharquia, Al Behaira and Al Giza were of $(31.2 \%, 22.4 \%$ and $18.6 \%)$ respectively. Mortality rate was higher in calves at first week of age $61.8 \%$ than at second week of age $38.2 \%$, as showed in Table (1). Similar results obtained by Pkinjavdekar et al. (1994) who said that the highest mortality during the neonatal stage was at few days after birth due to inadequate care in management of newborn calves. Also mortality rate was more prevalence in winter $69.4 \%$ than summer $30.6 \%$ Table (1). Season has a significant effect on the calf mortality as well as on the absorption of immunoglobulins in neonatal calves. In temperate climates the mean serum IgG1 concentrations were lowest in winter born calves and increased during the early summer (Khan, 1991), perhaps this is the reason of higher mortality rates had observed in winter born cattle calves than in summer born calves. Similar observations have been reported by Mourad \& Rashwan (2001).

Enteritis cases were recorded $(13.2 \%)$ while Pneumonia represented (28.4\%) and pneumoentritis were $(58.4 \%)$ from total number of dead calves, as shown in Table (2) and (Fig. 2a). Dead calf showed respiratory manifestations and/ or diarrhea ended by death within few days. Similar findings were reported by Radostits et al. (2009) and Abdelsalam, and ALSeaf (2013), who reported that, bad environmental condition, improper vaccination and in-adequate colostrums are considered a very dangerous stress factors that impaired calves' immune system which increased the risk of fatal infection in sucking calf.

\section{2 microbiological discussion:}

Szeredi et al. (2010) reported that, the infectious origin of fatal cases of calf pneumonia was studied in 48 calves from 27 different herds on postmortem examination. Pneumonia was diagnosed in $47 / 48$ cases and infectious agents were found in 40/47 $(85 \%)$ of those cases. The presence of multiple respiratory pathogens in $23 / 40 \quad(57.5 \%)$ cases indicated the complex origin of fatal calf pneumonia. The most important respiratory pathogens were $P$. multocida in 36/40 (90\%) cases, BVDV were found in $1 / 40(2.5 \%)$ in addition to other microbes.

In this study, bacteria and viruses isolated from suckling dead calves suffering from pneumonia, enteritis and pnemoentritis showed in table ( 3,4 and 5).

Both nasal swab and lung samples of (41) pneumonic dead suckling calves as showed in Table (3) and (Fig. $2 \mathrm{~b}$ ), the most prevalence was $P$. multocida which recovered 10 isolates $(6.9 \%)$ then BVD in 9 cases $(6.2 \%)$ in single infection on the other hand, the most observed result was the frequent association between $P$. multocida with BVDV as Mixed infection which represented as $(15.2 \%)$ of cases in this study. We suggest that this high incidence could be a result of pathogenic interaction between viral and bacterial pathogen this finding nearly comes in agreement with Fulton et al. (2009) and Zaher et al. (2014). Also Fulton et al. (2011) was isolated BVD from nasal swabs and lung tissues of dead calves.

Isolated bacteria and viruses from (19 cases) dead suckling calves that, suffering from enteritis as showed in Table (4) (Fig. 2c), S. typhimurium 4 $(2.7 \%)$ then E. coli $3(2.08 \%)$ and mixed infection of $B V D$ with E. coli $6(4.1 \%)$, and mixed infection of Rota virus with S. typhimurium $6(4.1 \%)$ these findings correlated with Bhat et al. (2012); Singla et al. (2013) and Muktar et al. (2015) who were reported that, BRV group A, and BVD as well as $S$. typhimurium and enterotoxigenic E. coli are known as the most common pathogens identified in scouring calves less than one months of age.

Rotaviruses (BRV) induce diarrhea in neonatal calves that have been exposed to virus contaminated milk, water and feed materials. In this work BRV were detected in feces of $6(4.1 \%)$ of calves by Immunofluorescence test (IFT) and Rotavirus Rapid Test Device (RRTD) as showed in Table (6- 7). This result may be explained as infected dam shedding virus in feces during late stages of pregnancy, thus providing a source of BRV infection to their calves more over BRV is causing localized infection in small intestine of neonatal calves by disrupting the efficient absorptive surfaces to produce diarrhea. This explanation comes consistent with the explanation of Madeley and Peiris (2002); Steele et al. (2004) and Malik et al. (2005).

Isolated bacteria and viruses from suckling dead calves suffering from pnemoentritis as showed in Table (5) (Fig. 2d) were Isolated organisms were mixed infection of BVDV with S. typhimurium and E. coli (13.8\%), other cases showed mixed infection of BVD with S. typhimurium (13.8\%), other cases showed mixed of P.multocida with S. typhimurium $(13.1 \%)$ finally cases of mixed infection of BVD with E.coli and P.multocida (18.7\%). Similar pnemoentrites isolates reported by Ronald (1989) and Brodersen et al. (1998). The immunesuppressive effect of BVDV infections can enhance the clinical disease of other pathogens and play an important role 
in multiple infectious diseases (Potgieter, 1997). In addition, BVDV depresses immunoglobulin and interferon production, reduces response of lymphocytes to mitogens and impairs monocyte chemotaxis. This depression of cell mediated immunity is accompanied by reduced humeral immuneresponse. (Jubb et al., 1993). Detection of BVDV antigen with rate of $60.41 \%$ in the nasal and fecal swabs as well as tissue samples that collected from dead calves using both indirect immunofluorescent antibody technique (IFAT) and Immunoperoxidase test (IPMA) techniques as showed in Table (6\&7) as described previously by Haines, (1992) and Brock, (1995). Also in this work we detected the NCP BVD in all of samples on the MDBK cell line. Our results were in agreement with Cornish (2005) and Kampa, (2006) who were detected NCP biotypes which associated with immunotolerance and persistent infection (PI), when immunotolerant calves exposed to BVDV during the first trimester of gestation, also there is evidence that non cytopathic BVDV inhibits apoptosis, that might prolong a mixed viral infection by interfering with cellular self-destruct mechanisms that limit viral replication (Schweitzer and Peterhans, 2001).

\section{Pathological findings:}

\subsection{Pneumonic calves:}

Viral and bacterial synergism in pneumonia diagnosis is an area of concern however, there have been an interest with the pathogenesis, epidemiology, and prognosis of mixed pneumonia. Some viruses as primary infection, interactions of the pulmonary microbiome as secondary infection or commensals, host immune response and prognosis or the combination effect of all of the above. Hanson and Couturier, (2016) and Cawcutt and Kalil (2017).

The lung revealed two types of pneumonia Acute fibrinosuppurative in 10 cases and Interstitial pleuropneumonia 31 cases out of 41 lung tissue (Table 8).

Grossly, lung from dead calves showed thickened pleura with adhesion, focal red purple lesions, multifocal sub pleural pale emphysematous lesions.

\section{1- Acute fibrinosuppurative pneumonia}

This type of pneumonia showed in 10 (6.9\%) of cases p. multocida Microscopically revealed accumulation of neutrophils, macrophages, with RBCS and fibrin in alveolar lumens, in addition to periaveolar vascular congestion (Fig. 3), thickening in the inter alveolar septa (Fig. 4). These pathological pulmonary lesions are coinciding with those described by Doster, (2010); Fulton et al. (2011) and Gerard et al. (2017) who recorded fibrinosuppurative bronchopneumonia (49\%) and interstitial pneumonia (48\%) in 136 dead cattle calf in Ireland due to $P$. multocida as single or mixed infection with viruses and bacteria. Our findings are probably due to the dynamic interaction between pulmonary intravascular macrophage (PIM) cellular and humeral components of the inflammatory response to endotoxin of pasteurellosis.

Ultrastructure examination of lung of those cases were demonstrated $P$. multocida as numerous short rod bacterial cells surrounded by halo space of both extra and intravascular in close association with the erythrocytes and endothelial cells (Fig. 5). The pneumocyte showed extensive disintegration of nuclear envelope, peripheral nuclear material condensation. The present study revealed that pathological changes that due to $P$. multocida are resulting from acute cellular response to large numbers of $P$. multocida in most cases as calves succumbed to the disease at the peak of the septicemic stage. Furthermore, invasion or translocation through endothelial cells is necessary for rapid invasion of the vascular system for septicemic disease as discussed previously by Shafarin et al. (2007).

\section{2- Interstitial pleuropneumonia}

This type of pneumonia recorded in 31(21.5\%) of cases, from which BVDV as single or mixed with, $P$. multocida were isolated.

Microscopically, Pleura, interstitial tissue and the inter alveolar septa revealed thickening due to mononuclear cell infiltrations as well as vasculitis (Fig. 6). Atelectasis, compensatory emphysema was noticed. In addition to eosinophilic fibrinous exudates intermingled with mononuclear inflammatory cells, red blood cells and coagulative necrotic foci in some parts. Bronchial epithelium revealed detachment of cilia as well as sub epithelial lymphocytic infiltrations (Fig. 7). Those findings come in agreement with Gagea et al. (2006b); Ridpath et al. (2010) and Gerard et al. (2017). The ultra-structural of lung tissues of those cases demonstrated BVDV particles as many electron-dense smaller membrane-bounded inclusions, in the ciliated bronchial epithelium (Fig. 8). In cases of mixed infection of BVDV and $P$. multocida this finding attributed to that BVDV play an important role, as a primary respiratory pathogen that induce immunosuppression and synergistic effects with other respiratory pathogens which causing pneumonia as $P$. multocida to enhanced its role to produces pneumonia and fibrinous pleuritis.

\subsection{Enteric calves}

This type was recorded in 19(13.2\%) of case, isolated microorganisms were E. coli $(2.08 \%)$ as single infection and with mixed BVDV (4.1\%). Also, $S$. typhimurium recovered as single infection $(2.7 \%)$ and mixed with Rota virus in $(4.1 \%)$ of cases.

Grossly, the Intestine showed ulcerative part specially in small intestine and congestion and ecchymotic hemorrhages at some places on their mucosa. 
Liver showed severe congested and edema. Mesenteric Ln. was hypertrophy. Our finding was in agreement with Jones et al. (1997).

\section{Intestine:}

Histopathological examination, revealed Hemorrhagic ulcerative enteritis characterized by Necrosis and detachment of epithelial cells with vascular congestion and inflammatory cell infiltrations as well as echmotic red blood cells in both intestinal mucosa and lamina propria.

By Transmission electron microscope (TEM) of intestine BVDV particles were detected as densely packed vesicles within enterocytes (Fig.9). Similar results were described by Aly et al. (2003) due to BVDV and explained by MaCGavin and Zachary (2007) as BVDV gain entrance to the to the epithelial linings of the intestinal mucosa resulting in necrotizing processes which leading to necrotic lesions of the surface and crypts. Moreover, intestinal infection of calves by $S$. typhimurium resulting in an acute severe infiltration of neutrophils, that due to the interaction of S. typhimurium with intestinal epithelial cells. This interaction leading to secretion of chemo attractant factors for neutrophils and chemokines (Reis et al., 2003). The basic mechanism illustrating that, Salmonella invade the intestinal epithelial cells and mucosa where it multiplicate in, then surviving within macrophages in lymphoid tissues, which ending by entero pathogenicity with systemic disease.

Liver: microscopically revealed severely dilated congested sinusoids and, lymphocytic infiltrations as well as perivascular fibrous tissue proliferations in the portal area with sporadic piknotic hepatocytes paynchyma (Fig.10). Ultra structurally, hepatocytes of calf showed marked peripheral nuclear condensation due to nucleoplasmic rarefaction and nuclear membrane fragmentation. There was cytoplasmic edema, mitochondrial swelling, cristolysis and matrix lysis (Fig.11).

Mesenteric lymph nodes revealed lymphoid depletion with subcabsolar oedema, peri trabecular hemorrhages and cellular infiltrations in some cases by Transmission electron microscope (TEM), viral particles were present within reticuloendothelial cells of mesenteric lymph nodes (Fig. 12).

\section{3. pneumentric calf}

Represented in $84(58.4 \%)$ cases of dead examined calf. Isolated organisms were mixed infection of BVDV with $S$. typhimurium and E. coli (13.8\%), other cases showed mixed infection of BVD with $S$. typhimurium $(13.8 \%)$, other cases showed mixed of P.multocida with $S$. typhimurium (13.1\%) finally cases of mixed infection of BVD with E.coli and P.multocida (18.7\%). Table (8).
Grossly, lung showed congestion, multifocal small erosions /or ulcerations in the small and large intestines. The heart showed endocardial focal petechial hemorrhages (Fig. 13). Spleen and kidneys were severely congested, edematous and hypertrophied including (Kanel and Korula, 2005).

\section{Lung:}

Lung showed Fibrino-necrotizing bronchopneumonia characterized by Bronchiolar epithelial cells revealed loss of cilia, necrosis with denudation within the lumen leaving areas of ulceration and erosion. Other parts of bronchial epithelial showed hyperplastic proliferations that occluding the lumen and lymphocytic peribronchiolar cuffing. (Fig. 14). The alveolar septa often contained lymphocytes and macrophages, Fulton et al. (2011) reported that Rota virus primarily isolated from lungs of dead calves that showing interstitial pneumonia, emphysema and winter dysentery as single or in multiple infections including BVDV, P. multocida and E. coli. Morris et al. (2011) were considered those lesions as common findings with pneumonic pasteurellosis alone or in combination with BVDV, explained as exposure to respiratory viruses, such as BVD, usually impair the local pulmonary defense mechanisms through causing severe respiratory epithelium damage, that predisposes for entry of opportunities pathogenic bacterial infection for attachment, multiplication and reach lungs followed by Endotoxins production. Moreover, BVDV enhanced the alveolar macrophages procoagulant activity, which could lead to increased fibrin deposition in the lung. In addition to enhanced enteric disease in mixed infections, leading to severe pneumo enteric disease which is supportive of the findings of our study.

Intestine showed Necrotizing ulcerative enteritis: Microscopically, there were various alterations manifested by necrotizing enteritis, inflammatory cell infiltration, necrosis of intestinal villi and vasculitis of some submucosal blood vessels. Some intestinal crypts showed hypertrophied (Fig. 15). In addition to epithelial lining of the intestinal gland showed goblet cell hyperplasia with peri glandular inflammatory cell infiltrations.

Ultra-structural of intestinal epithelial cells from calves with mixed infection showed damaged microvilli, and absence of the apical tubular system. Some villus epithelial cells had Rota virus particles which centrally located, round, electron-dense core about 25 to $30 \mathrm{nmin}$ diameter surrounded by one or two membranes. The Rota virus particles were located in dilated cisternae of rough endoplasmic reticulum (Fig.16). These finding come in coordinate with Muktar et al. (2015). The rotavirus infection destruction the villus epithelial cells, cause lysis of infected cells as evidenced by vacuolation, an overall 
cellular loss of electron density, loss of microvilli and disappearance of the apical tubular system.

Kidney: Microscopically, interstitial glomerulonephritis was noticed characterized by sever peritubular vascular congestion with lymphocytic infiltrations. Other renal tubules showed coagulative necrosis and detachments of epithelial lining with pronounced vasculitis (Fig.17). Our findings confirmed by those of Kumar et al. (2005) and MacGavin and Zachary (2007) who reported that by BVDV infection an antigen antibody complex formed in circulation which trapping in the glomeruli and inducing glomerular damages with renal interstitial leukocytic infiltration.

Ultrastructurally kidneys, in some cases showed $P$. multocida attached to the basement membrane of capillaries, and within the cytoplasm of lysed tubular epithelium of kidneys (Fig.18). Affected tubular cells appeared destructed, disintegrated andlysised (Aly et al. 2003).

Heart: Microscopically revealed Acute hemorrhagic myocarditis. Cardiac muscle revealed edema with vascular congestion and lymphocytic infiltrations as well as vasculitis. Some parts showed hemorrhages in between cardiac muscle cells and necrosis of the cardiac myocytes. Ultrastructure of Cardicmyocytes showed dentated nucleus and numerous mitochondria. Also the perinucleur areas contain light zoon material manifesting edema of the cell (Fig.19). Similar findings were previously recorded by Ibtisam et al. (2000) and Haines et al. (2004) in calves with pneumoentrites due to microbial infection of bacteria and virus potential adhere to invade cells by translocation may constitute a mechanism which enables the bacteria invade the bloodstream and give its pathogenic effect on cardicmyocytes.

\section{Spleen:}

Spleens revealed sever lymphoid depletion with subcapsular oedema, and cellular infiltrations as well as pronounced sever vasculitis (Fig.20). Similar pnemoentrites, splenic lymphoid depletion and septicemia were recorded by Ronald (1989) BVDV and Rota virus were related those lesions to immune suppressive effect of virus which lead to ascending of bacteria from disrupted gastrointestinal tracts and produced toxemia.

\section{CONCLUSION}

Inadequate intake of colostrum, poor hygiene, overcrowding in the calf pens, air contamination, close proximity to adult cows, mixing of different age groups and improper vaccination program are the major risk factors for dangerous viral and bacterial infection lead to high calf mortality rate in the three covered governrates in lower Egypt. BVDV have immunosuppressive effect and facilitate secondary infection in diseased calves, which subsequently results in high economic losses and persistent infection (PI) animals considered major threat for cattle. So, it is recommended that the identification of PI animals and removing for control against BVDV. It is critical to collect all viral and bacterial strains from all separat Upper Egypt Governorates and make alocal vaccines for most important epidemic micro-organismes as we can as possible.

\section{REFERENCES}

Abdelsalam, M.M. and AL-Seaf, A.M. (2013): An outbreak of Bovine Respiratory Disease in calves: Clinical and Histopathological findings Journal of Agricultural and Veterinary Sciences Qassim University, Vol. 6, No. 2, pp. 89-99 (July /Sha'ban 1434H).

Aly, NM.; Shehab, GG. and Abd EL-Rahim (2003): "Bovine viral diarrhea, bovine herpes virus and parainfluenza- 3 virus infections in three cattle herds in Egypt.” Rev. Sci. Aff. Int. Epiz., 22; (3): 879-892.

Azizzadeh, M.; Shooroki, HF.; Kamalabadi, AS. and Stevenson, MA. (2012): Factors affecting calf mortality in Iranian Holstein dairy herds. Preventive Veterinary Medicine 104, 335-340

Baily and Scott (1998): "Diagnostic microbiology." $10^{\text {th }}$ Ed., Mosby Company, USA.

Bartels, CJ.; Holzhauer, M.; Jorritsma, R.; Swart, WA. and Lam, TJ. (2010): Prevalence, prediction and risk factors of enteropathogens in normal and non-normal faeces of young Dutch dairy calves. Prev. Vet. Med., 93, 162169.

Bhat, SA.; Juyal, PD. and Singla, LD. (2013): Bovine cryptosporidiosis: brief review of its distribution in india. Trends Parasitol. Res. 2(2): 5-13.

Brock, KV. (1995): Diagnosis of BVDV infection. Vet. Clin. N. Am. Food. Anim. Pract. 11: 549561.

Brodersen, BW. and Kelling, CL. (1998): Effect of concurrent experimentally induce bovine respiratory syncytial virus and bovine viral diarrhoea virus infection on respiratory tract and enteric diseases in calves. Am. J. Vet. Res., 59:1423-1430.

Cawcutt, K.A. and Kalil, A.C. (2017): Viral and bacterial co-infection in pneumonia: do we know enough to improve clinical care? Critical Care 21:19

Cornish, T.E.; Van Olphen, L.A. and Cavender, J.L. (2005): 'Comparison of ear notch immunohistochemistry, ear notch antigencapture ELISA, and buffy coat virus isolation for detection of calves persistently infected 
with bovine viral diarrhea virus', Journal of Veterinary Diagnostic

Crook, T.; Benavides, J.; Russell, G.; Gilray, J.; Maley, M. and Willoughby, K. (2012): Bovine herpesvirus 1 abortion: current prevalence in the United Kingdom and evidence of hematogenous spread within the fetus in natural cases Investigation. Journal of Vet. Diag; 24: 662-670.

Dhama, K.; Chauhan, R.S.; Mahendran, M. and Malik, S.V. (2009): Rotavirus diarrhea in bovines and other domestic animals. Vet Res Commun 33:1-23.

Doster, A.R. (2010): Bovine Atypical Interstitial Pneumonia. Veterinary Clinics of North America: Food Animal Practice, Volume 26, Issue 2, July Pages 395-407.

Fulton, R.W.; Douglas, L.S.; Jackie, W.L.; Burge, ME.; Payton, B.J.; Cook, DB.; Chris, JR. and Anthony, WC. (2011): Bovine coronavirus (BCV) infections in transported commingled beef cattle and sole-source ranch calves Can. J. Vet. Res. Jul; 75(3): 191-199.

Fulton, RW.; Blood, KS.; Panciera, RJ.; Payton, ME.; Ridpat, JF.; Confer, AW.; Saliki, JT.; Burge, LT.; Welsh, RD.; Johnson, BJ. and Reck, A. (2009): Lung pathology and infectious agents in fatal feedlot pneumonias and relationship with mortality, disease onset, and treatments. J Diagnos Invest 21:464-77.

Gagea, MI.; Bateman, KG.; Dreumel, T.; McEwen, B.J.; Carman, S.; Archambault, M.; Shanahan, RA. and Caswell, JL. (2006b): "Naturally occurring Mycoplasma bovis associated pneumonia and polyartheritis in feedlot beef calves J. Vet. Diag. Invest., 18 (1): 29-40

Gerard, M.M.; Simon, J.M.; Dónal, S.M.; Casey, M.C.; McElroy, R.G.; O’Neill, W.J.; Byrne, B.E.; Tracy, A.C.; Bell, C.J. and Cassidy, JP. (2017): Pathogens, patterns of pneumonia, and epidemiologic risk factors associated with respiratory disease in recently weaned cattle in Ireland Journal of Veterinary Diagnostic Investigation Vol 29, Issue 1.

Haines, DM.; Clark, EG. and Dubovi, EJ. (1992): Monoclonal antibody based immune histochemical detection of bovine viral diarrhea virus in formalin-fixed, paraffinembedded tissues. Vet. Pathol., 29 (1), 27-32

Haines, DM.; Moline, KM.; Sargent, RM.; Camphell, JR. and Doig, P.A. (2004): Immuno histolchemical study of Hemophilus Somnus, Mycoplasma bovis, Mannheimia haemolytica, and bovine viral diarrhea virus in death losses due to myocarditis in feedlot cattle." Canadian Vet. J., 45 (e): 231-234.

Hanson, KE. and Couturier, MR. (2016): Multiplexed molecular diagnostics for respiratory, gastrointestinal, and central nervous system infections. Clin Infect Dis. 63(10): 1361-7.
Ibtisam, M.G.; El Din; Mohga, Showkat; El Din, M.M. Mouxhira and Ali, A. (2000): "Diagnostic studies of bovine viral diarrheamucosal disease in Sharkia governorate." Assiut Vet. Med. J., 43; (85): 210-224.

Intisar, KS.; Ali, YH.; Khalafalla, AI.; Rahman, EA.; Mahasin, M. and Amin, AS. (2009): Natural exposure of Dromedary camels in Sudan to infectious bovine rhinotracheitis virus (bovine herpes virus-1). Acta Tropica; 111: 243-46.

Jones, T.C., Hunt, R.D. and King, N.W. (1997): Veterinary Pathology, 6th Ed, Williams \& Wilkins.

Jubb, K.V.F.; Peter, C.K. and Palmer, N. (1993): Pathology of domestic animals " $4^{\text {th }}$ Ed. Acadmic press Inc. U.S.A.

Kamaraj, G.; Rana, SK. and Srinivasan, VA. (2009): Serological response in cattle immunized with inactivated oil and Algel adjuvant vaccines against infectious bovine rhinotracheitis. New Microbiologica 32: 135-41.

Kampa, J. (2006): 'Epidemiology of bovine virus diarrhea virus and bovine herpesvirus type 1 infection in dairy cattle herds', PhD thesis, Dept. of Clinical Sciences, Swedish University of Agricultural Sciences

Kanel, G. and Korula, J. (2005): Atlas of Liver Pathology, 2nd Edition. Elsevier Saunders Publishing, pp36

Khan, M. (1991): Atiopathology of neonatal calf mortality Journal of Islamic Academy of Sciences 4:2, 159-165, 75

Kodjo, A.; Villard, L.; Bizet, C.; Martel, J.; Sanchis, R.; Borges, E.; Gauthier, D.; Maurin, F. and Richard, Y. (1999): "Pulsed-field gel electrophoresis is more efficient than ribotyping and random amplified polymorphic DNA analysis in discrimination of Pasteurella haemolytica strains." J. Clin. Microbiol., 37: 380-385.

Kumar, V.; Abbas, K. and Fausten, N. (2005): "Robbins and Cotran, pathologic basis of diseases." $7^{\text {th }}$ Ed., Elsevier, Inc. USA.

MacGavin, M.D. and Zachary, J.F. (2007): Pathological Basis of Veterinary Disease " $4^{\text {th }}$ Ed Mosby, Elsiver. U.S.A.

Madbouly, HM.; Sagheer, MB.; Ata, NS.; Kutkat, MA. and Zaher, KS. (2005): Identification and purification of a local isolate of infectious laryngotracheitis virus. Egyptian Journal of Veterinary Science2005; 39: 11-20.

Madeley, CR. and Peiris, JS. (2002): Methods in virus diagnosis: immunofluorescence revisited. J Clin Virol.; 25: 121-134.

Malik, S.V.S.; Barbuddhe, S.B.; Rawool, D.B.; Vaidya, V.M. and Sahare, A.M. (2005): Data sheet on Rotaviruses (Global status of Rotavirus infections in man and animals), In: Animal Health and Production Compendium, CAB International, Wallingford, U. 
Martin, SW.; Meek, AH. and Willeberg, P. (1987): Veterinary epidemiology, (Iowa State University, Library of Congress).

Meyling, A. (1984): Detection of BVD virus in viremic cattle by an indirect immunoperoxidase technique. In Recent advances in virus diagnosis. Martinus Nijhoff, The Hague, 37-4660.

Morris, W.E.; 1 Agustı'n J. Venzano; Ana Elizondo; Daniel A. Vilte; Elsa C. Mercado and Mariano E. Fernandez-Miyakawa, J. (2011): Necrotic enteritis in young calves Vet. Diagn Invest 23: 254-259

Mourad, M. and Rashwan, S. (2001): Milk Production of Buffaloes and Causes of Calf Mortalityunder a Semi-Intensive Production System in EgyptRevue Élev. Méd. vét. Pays trop., 54 (2): 139-145.

Muktar, Y.; Gezhagne, M.; Biruk, T. and Dinaol, B. (2015): A review on major bacterial causes of calf diarrhea and its diagnostic method Journal of Veterinary Medicine and Animal Health Vol. 7(5), pp. 173-185, May

Nour mohammad zadeh, F.; Davoudi, Y.; Abdollahpour, G. and Nouri, A. (2011): The prevalence of rotavirus in neonatal calf diarrhoea, using electron microscopic examination. Comparative Clinical Pathology

OIE (1992): Manual of diagnostic tests and vaccine for terrestrial animals.

Pardon, B.; Bleecker, K.; Hostens, M.; Callens, J.; Dewulf, J. and Deprez, P. (2012): Longitudinal study on morbidity and mortality in white veal calves in Belgium Veterinary Research 8:26.

Pkijavdekar, T.; Sriastava, B.B. and Lpnautity, LL. (1994): Mortality pattern in calves. Indian J. Anim. Sci., 64: 811-812.

Potgieter, LN. (1997): Bovine respiratory tract disease caused by bovine viral diarrhea virus. Vet Clin North Am Food Anim Pract 13:471481.

Radostits, OM.; Gay, CC.; Hinchcliff, KW. and Constable, PD. (2009): Veterinary Medicine $10^{\text {th }}$ ed. Bailliere, London, U.K.

Razzaque, MA.; Al-Mutawa, T.; Abbas, S. and Bedair, M. (2009): Performance of pre-weaned dairy calves under hot arid environment: effects of immunoglobulins and age on diseases and mortality. American Journal of Applied Sciences 6, 1885-1891.

Reis, BP.; Zhang, SP.; Tsolis, RM.; Bäumler, AJ.; Adams, LG. and Santos, RL. (2003): The attenuated sopB mutant of Salmonella enterica serovar Typhimurium has the same tissue distribution and host chemokine response as the wild type in bovine Peyer's patches. Vet Microbiol, 97, 269-277.

Ridpath, J. (2010): The Contribution of Infections with Bovine Viral Diarrhea Viruses to Bovine
Respiratory Disease. Vet. Clin. Food Anim. 26: 335-348.

Ronald, E.; Werdin, T.R.; Ames, SM. and Goyal, G.P. (1989): Diagnostic investigation of bovine viral diarrhea infection in a Minnesota dairy herd J. Vet. Diagn Invest 1:57-61

Schweizer, M. and Peterhans, E. (2001): Noncytopathic bovine viral diarrhea virus inhibits double-stranded RNA-induced apoptosis and interferon synthesis. J. Virol.; 75: 4692-4698(149).

Shafarin, MS1.; Zamri-Saad, M.; Jamil, SM.; Siti Khairani, B. and Saharee, AA. (2007): Experimental transmission of Pasteurella multocida 6: B in goats. J. Vet. Med. A Physiol Pathol Clin. Med. Apr; 54(3): 136-9.

Shoshani, R.G.; Vimalanathan, S.; Prema, D.; Church, JS.; Reudink, MW.; Nation, N. and Miller, CC. (2013): Safety, bioavailability and mechanism of action of nitric oxide to control Bovine Respiratory Disease Complex in calves entering a feedlot. Res. Vet. Sci. 12 (30): 30-5.

Singla, LD.; Gupta, MP.; Singh, H.; Singh, ST.; Kaur, P. and Juyal, PD. (2013): Antigen based diagnosis of Cryptosporidium parvum infection in cattle and buffalo faeces. Indian J. Anim. Sci. 83: 37-39

Steele, A.D.; Geyer, A. and Gerdes, G.H. (2004): Rotavirus infections. In: Coetzer, J.A.W. and Tustin, R.C. (eds), Infectious diseases of Livestock, Oxford University Press, Southern Africa, 1256-1264

Suvarna, K.S.; Layton, C. and Bancroft, J.D. (2013): Bancroft's Theory and Practice of Histological Techniques, by Suvarna, 7th Edition Churchill Livingstone.

Szeredi, L.; Jánosi, S. and Pálfi, V. (2010): Microbiological and pathological examination of fatal calf pneumonia cases induced by bacterial and viral respiratory pathogens. Acta Vet Hung. Sep;58(3): 341-56.

Torres, S.; Thomson, DU.; Bello, NM.; Nosky, BJ. and Reinhardt, CD. (2013): Field study of the comparative efficacy of gamithromycin and tulathromycin for the control of undifferentiated bovine respiratory disease complex in beef feedlot calves at high risk of developing respiratory tract disease. Am. J. Vet. Res. 74(6): 839.

Voiriot, G.; Visseaux, B.; Cohen, J.; Nguyen, LB.; Neuville, M.; Morbieu, C.; Burdet, C.; Radjou, A.; Lescure, FX. and Smonig, R. (2016): Viralbacterial coinfection affects the presentation and alters the prognosis of severe communityacquired pneumonia. Crit Care. 20(1): 375.

Zaher, K.S.; Sohier, MS.; Hanan, M.; Elhewairy Hanan, S. and Marie, H. (2014): Investigation of Bovine Respiratory Disease Complex in Egypt with Emphasis on Some Viral and Bacterial Pathogens. Life Sci. J. 11(6): 56-62. 


\section{دراسات ميكروبيولوجية وياثولوجية على معدلات النفوق المرتفعة فى العجول الرضيعة مع المرجعية الخاصة لبعض الار اسات الوبائية}

اشبرف نبيه محد ، نبيال عبل العلبيم حسن ، هناء على الحلوانس ، هالة عبل الرحيم سالم ، حد هانح محد فتحى

Email: ashraf_nabih27@yahoo._ Assiut University web-site: www.aun.edu.eg

اجريت هذه الدراسة للوقوف على أسباب ارتفاع معدل الوفيات في العجول الرضيعة والتعرف على المسببات البكتيرية والفيروسية

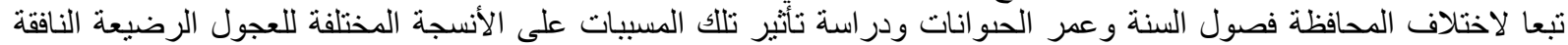

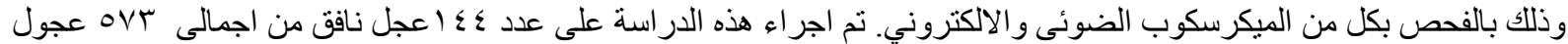

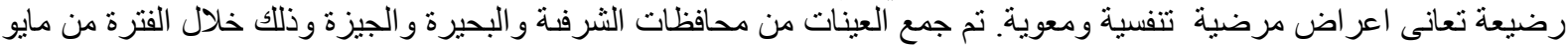

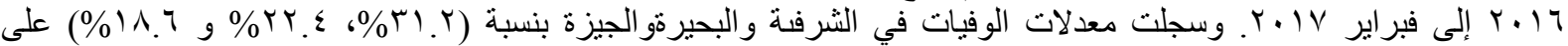

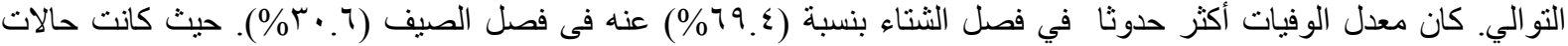

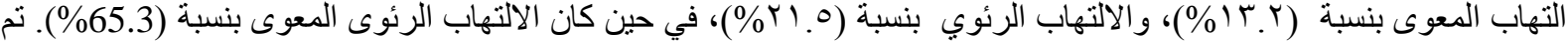

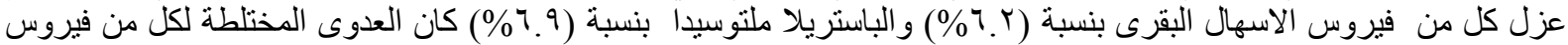

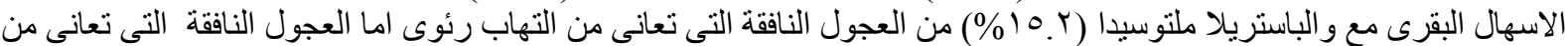

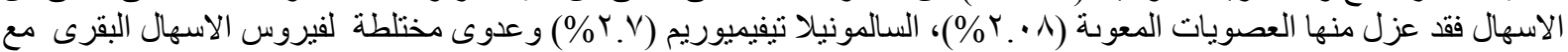

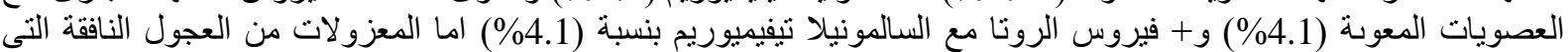

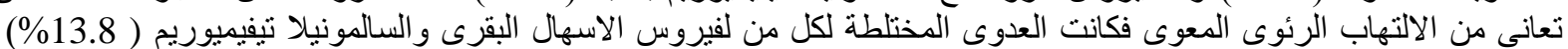

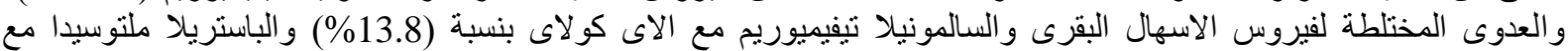

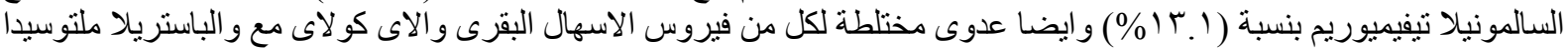

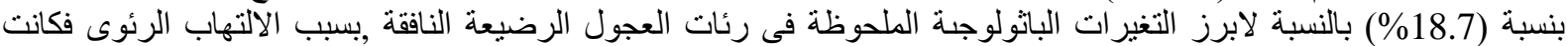

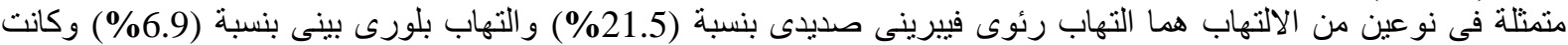

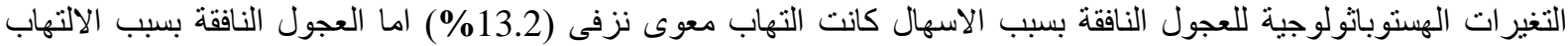

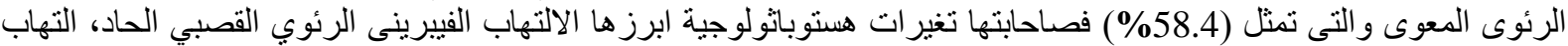

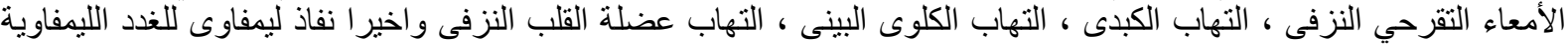

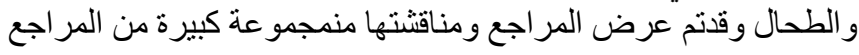

